\title{
Sensitivity of Colletotrichum Species, Including C. fioriniae and C. nymphaeae, from Peach to Demethylation Inhibitor Fungicides
}

S. N. Chen and C. X. Luo, College of Plant Science and Technology, Huazhong Agricultural University, Wuhan 430070, China; and M. J. Hu and G. Schnabel, Department of Agricultural and Environmental Sciences, Clemson University, Clemson, SC 29634

\begin{abstract}
Chen, S. N., Luo, C. X., Hu, M. J., and Schnabel, G. 2016. Sensitivity of Colletotrichum species, including C. fioriniae and C. nymphaeae, from peach to demethylation inhibitor fungicides. Plant Dis. 100:2434-2441.

Few fungicides are effective against anthracnose, caused by Colletotrichum spp., and emerging resistance makes the search for chemical alternatives more relevant. Isolates of the Colletotrichum acutatum species complex were collected from South Carolina and Georgia peach orchards and phylogenetic analysis of the combined internal transcribed spacer region, glyceraldehyde-3-phosphate dehydrogenase, and $\beta$-tubulin gene sequences separated the isolates into $C$. nymphaeae and $C$. fioriniae. The sensitivity of these and three other previously reported Colletotrichum spp. from peach, including $C$. fructicola, $C$. siamense, and $C$. truncatum, to demethylation inhibitor (DMI) fungicides difenoconazole, propiconazole, tebuconazole, metconazole, flutriafol, and fenbuconazole was determined based upon mycelial growth inhibition. C. truncatum was

resistant to tebuconazole, metconazole, flutriafol, and fenbuconazole and $C$. nymphaeae was resistant to flutriafol and fenbuconazole based on $50 \%$ effective concentration $\left(\mathrm{EC}_{50}\right)$ values $>100 \mu \mathrm{g} / \mathrm{ml}$. C. fructicola and $C$. siamense were sensitive to all DMI fungicides $\left(\mathrm{EC}_{50}\right.$ values of 0.2 to $13.1 \mu \mathrm{g} / \mathrm{ml})$. C. fioriniae subgroup 2 isolates were less sensitive to DMI fungicides $\left(\mathrm{EC}_{50}\right.$ values of 0.5 to $16.2 \mu \mathrm{g} / \mathrm{ml}$ ) compared with $C$. fioriniae subgroup $1\left(\mathrm{EC}_{50}\right.$ values of 0.03 to $\left.2.1 \mu \mathrm{g} / \mathrm{ml}\right)$. Difenoconazole and propiconazole provided the best control efficacy in vitro to all five species, with $\mathrm{EC}_{50}$ values of 0.2 to $2.7 \mu \mathrm{g} / \mathrm{ml}$. Tebuconazole and metconazole were effective against all Colletotrichum spp., except for $C$. truncatum. The strong in vitro activity of some DMI fungicides against Colletotrichum spp. may be exploited for improved anthracnose disease management of peach.
\end{abstract}

Anthracnose of peach is mainly caused by Colletotrichum acutatum J. H. Simmonds and C. gloeosporioides (Penz.) Penz. \& Sacc. (Bernstein et al. 1995; Kim and Hong 2008; Ramsey et al. 1951; Schnabel et al. 2006). Recently, a third species, C. truncatum, was also reported to cause peach anthracnose in South Carolina (Grabke et al. 2015). Numerous studies have reported $C$. gloeosporioides and C. acutatum to be species complexes (Damm et al. 2012; Weir et al. 2012) but, for peach, only subspecies of C. gloeosporioides were recently delimited (Hu et al. 2015a). Anthracnose often occurs during high rainfall and warm temperatures (Ogawa et al. 1995). Symptoms include sunken and firm lesions with circular rings.

C. acutatum and C. gloeosporioides are morphologically very similar but there are some characteristic differences. Conidia of C. acutatum have acute ends (Simmonds 1965), while those of C. gloeosporioides have rounded ends (Wharton and Diéguez-Uribeondo 2004). Several other characteristics such as culture morphology, conidium size, mycelial growth rate, optimum growth temperature, and sensitivity to methyl benzimidazole carbamates (MBC) fungicides also can separate them (Adaskaveg 2000; Peres et al. 2004). However, morphological features may change during repeated subculture, conidial shapes may vary, and fungicide sensitivity can change. Therefore, taxonomical and phenotypical methods have to be used with caution (Damm et al. 2012; Weir et al. 2012) and supported by molecular characterizations (Weir et al. 2012).

Recently, the C. acutatum species complex was separated using multilocus molecular phylogenetic analysis and 31 species were accepted to be members (Damm et al. 2012). C. gloeosporioides was distinguished into 22 species using similar tools (Weir et al. 2012). Among them are two species, $C$. fructicola and $C$. siamense,

Corresponding author: G. Schnabel; E-mail: schnabe @clemson.edu

Technical Contribution Number 6429 of the Clemson University Experiment Station.

Accepted for publication 2 July 2016.

http://dx.doi.org/10.1094/PDIS-04-16-0574-RE

(C) 2016 The American Phytopathological Society identified recently to cause anthracnose of peach in South Carolina (Hu et al. 2015b).

Chemical management of anthracnose is a challenge because few chemical classes are effective. Apart from multisite fungicides such as captan, the most commonly used chemical classes for anthracnose control are the benzimidazoles (against $C$. gloeosporioides) and quinone outside inhibitor fungicides. However, their widespread use over recent decades has led to resistance problems with both chemical classes of fungicides $(\mathrm{Hu}$ et al. 2015a; Wong and Midland 2004; Young et al. 2010). Sterol demethylation-inhibitor fungicides (DMI) are widely used against fungal plant pathogens due to their broad-spectrum activity, more favorable toxicity profile compared with many protectants, and postinfection activity (Szkolnik 1981). In stone fruit, they became the mainstay for brown rot control after resistance to the benzimidazoles led to control failures (Jones and Ehret 1976; Michailides et al. 1987; Ogawa et al. 1984; Sonoda and Ogawa 1982) and they are still used extensively for preharvest brown rot control (Horton et al. 2016). The triazoles difenoconazole, propiconazole, tebuconazole, metconazole, flutriafol, and fenbuconazole are currently registered to control peach diseases (Horton et al. 2016) and recent research suggests that some DMI fungicides may be used to manage Colletotrichum spp. as well (Gopinath et al. 2006; Shetty et al. 2014; Towers et al. 2003).

The objective of this study was to phylogenetically characterize isolates from the $C$. acutatum species complex collected from peach orchards in South Carolina and Georgia and to determine the sensitivity of all Colletotrichum spp. known to cause anthracnose of peach to DMI fungicides.

\section{Materials and Methods}

Fungal isolates and culture conditions. Colletotrichum spp. were isolated from anthracnose-symptomatic peach fruit from commercial peach orchards, as described previously (Hu et al. 2015b). In all, 12 Colletotrichum isolates were collected from Georgia in 2015 and more than 100 were collected from South Carolina in 2004 (Schnabel et al. 2006). Fruit was surface disinfested in $10 \%$ bleach for $2 \mathrm{~min}$, then rinsed with distilled water. A cube of necrotic tissue ( 2 by 2 by $2 \mathrm{~mm}^{3}$ ) was cut from the symptomatic area and placed on acidified potato dextrose agar (PDA). Spores were 
obtained by incubating the plates at $25^{\circ} \mathrm{C}$ with a 12 -h cycle of fluorescent light. For single-spore isolation, conidia were scraped off the plate and suspended in $1 \mathrm{ml}$ of sterile distilled water. The conidial suspension $(50 \mu \mathrm{l})$ was spread on $1.5 \%(\mathrm{wt} / \mathrm{vol})$ water agar and incubated at $25^{\circ} \mathrm{C}$ overnight. One germinated conidium was transferred onto PDA and incubated at $25^{\circ} \mathrm{C}$ with a 12-h cycle of fluorescent light to induce sporulation. Each isolate was stored on filter paper (Whatman Inc., Maidstone, UK) as dried mycelium at $-20^{\circ} \mathrm{C}$ (Zhu et al. 2012).

The C. gloeosporioides and C. truncatum isolates used in this study were revived from storage (Grabke et al. 2015; Hu et al. 2015b). They originated also from peach and were collected and characterized previously (Grabke et al. 2015; Hu et al. 2015b). Isolates were recovered from stock cultures stored with silica blue gel beans at $-20^{\circ} \mathrm{C}$ on dried filter paper discs (Fisher Scientific, Pittsburgh; Table 1). The isolates from storage were grown for 5 days on PDA before being used for experiments.

Fungicides. Six DMI fungicides were used for sensitivity study: difenoconazole (Inspire EC; Syngenta Crop Protection, Research Triangle Park, Raleigh, NC), propiconazole (PropiMax EC; Dow AgroSciences, Indianapolis, IN), tebuconazole (Elite 45 DF; Bayer CropScience, Morrisville, NC), metconazole (Quash 50 WDG; Valent USA, Walnut Creek, CA), flutriafol (Topguard 11.8\%; Cheminova, Wayne, NJ), and fenbuconazole (Indar 75 WSP; Dow AgroSciences). These triazoles were selected because they are currently registered for disease management of peach in the United States.

DNA extractions, polymerase chain reaction amplification, and sequencing. Five isolates of $C$. nymphaeae, seven isolates of $C$. fioriniaesubgroup 2, and three isolates of $C$. fioriniae-subgroup 1 were selected for phylogenetic analysis (Table 1). All of them were grown on PDA at $25^{\circ} \mathrm{C}$ for 8 days in the dark. Single agar plugs containing actively growing mycelium were transferred to 250 -ml flasks containing $40 \mathrm{ml}$ of potato dextrose broth. Flasks were shaken at $120 \mathrm{rpm}$ for 3 days at $25^{\circ} \mathrm{C}$. Mycelium was filtered from the broth, rinsed under sterile deionized water, and subjected to DNA extraction using the DNeasy Plant Mini Kit (Qiagen Inc., Valencia, CA) according to the manufacturer's instructions.

The 5.8S nuclear ribosomal gene with the two flanking internal transcribed spacers (ITS) were amplified by primer set ITS-1F
(Gardes and Bruns 1993) + ITS-4 (White et al. 1990). A 240-bp intron of glyceraldehyde-3-phosphate dehydrogenase $(G A P D H)$ was amplified by primer set GDF1 + GDR1 (Guerber et al. 2003), and a 540-bp fragment of $\beta$-tubulin (TUB2) was amplified and sequenced using the primer pair Btub2Fd 5'-GTB CAC CTY CAR ACC GGY CAR TG-3') and Btub4Rd (5'-CCR GAY TGR CCR AAR ACR AAG TTG TC-3') (Woudenberg et al. 2009). Amplifications were performed using a T100 Bio-Rad thermal cycler (Bio-Rad Laboratories Inc., Hercules, CA) in a total volume of $25 \mu \mathrm{l}$. The polymerase chain reaction (PCR) mixtures contained $1 \times$ PCR buffer, $20 \mathrm{ng}$ of template DNA, $0.6 \mu \mathrm{M}$ each primer, $200 \mu \mathrm{M}$ each $\mathrm{dNTP}$, and $1 \mathrm{U}$ of Taq DNA polymerase (New England Biolabs, Ipswich, MA). Conditions for PCR of ITS regions constituted an initial denaturation step of $5 \mathrm{~min}$ at $94^{\circ} \mathrm{C}$; followed by 35 cycles of $30 \mathrm{~s}$ at $94^{\circ} \mathrm{C}, 30 \mathrm{~s}$ at $53^{\circ} \mathrm{C}$, and $30 \mathrm{~s}$ at $72^{\circ} \mathrm{C}$; and a final extension step of $7 \mathrm{~min}$ at $72^{\circ} \mathrm{C}$. For the $G A P D H$ region, the 35 cycles consisted of $30 \mathrm{~s}$ at $94^{\circ} \mathrm{C}, 1 \mathrm{~min}$ at $60^{\circ} \mathrm{C}$, and $30 \mathrm{~s}$ at $72^{\circ} \mathrm{C}$; for the $T U B$ region, cycles consisted of $30 \mathrm{~s}$ at $94^{\circ} \mathrm{C}, 30 \mathrm{~s}$ at $52^{\circ} \mathrm{C}$, and $30 \mathrm{~s}$ at $72^{\circ} \mathrm{C}$. Sequencing was conducted at the DNA Core Laboratory at Arizona State University (Tempe AZ).

Phylogenetic analysis. Phylogenetic analysis was conducted for the combined data matrix of the three loci (ITS, GAPDH, and TUB2). Multiple alignments were conducted using DNASTAR (DNASTAR Inc., Nevada City, CA) and CLUSTAL X v. 2.1 (Larkin et al. 2007; Thompson et al. 1997). ITS, GAPDH, and TUB2 nucleotide sequences of $C$. acutatum species complex were obtained from GenBank as reference sequences, including those for $C$. nymphaeae, C. guajavae, C. scovillei, C. chrysanthemi, C. walleri, C. simmondsii, C. brisbanense, C. paxtonii, C. sloanei, C. indonesiense, C. laticiphllum, C. lupini, C. melonis, C. tamarilloi, C. limetticola, C. acutatum, C. fioriniae, C. sallcis, C. johnstonii, C. pyricola, C. godetiae, C. australe, C. acerbum, C. rhombiforme, C. kinghornii, C. phormli, and $C$. orchidophilum (Table 2). The maximum-parsimony (MP) tree was constructed by Mega 5.0 software (Tamura et al. 2011) using the MP method (Thompson et al. 1997) and computed with the SubtreePruning-Regrafting (level =1). A brand-swapping method with initial trees was generated by random addition (100 reps). A complete deletion option was used to treat gaps or missing data and the reliability of clusters was evaluated by bootstrapping with 1,000 replicates. For the maximum-likelihood (ML) tree, the following settings were

Table 1. Species, name, origin, and year of isolation of Colletotrichum isolates from peach used in this study

\begin{tabular}{|c|c|c|c|c|}
\hline Species complex or species & Subspecies & Isolates & Origin (county, state) & Year of isolation \\
\hline \multirow[t]{6}{*}{ Colletotrichum gloeosporioides ${ }^{\mathrm{x}}$} & C. fructicola & Cg_RR12_3 & Spartanburg, SC & 2012 \\
\hline & & Cg_RR12_1 & Chesterfield, SC & 2013 \\
\hline & & Cg_SE12_1 & Spartanburg, SC & 2012 \\
\hline & C. siamense & Cg_Ey12_1 & Saluda, SC & 2012 \\
\hline & & Cg_OD13_2 & Saluda, SC & 2012 \\
\hline & & Cg_Ey12_10 & Aiken, SC & 2012 \\
\hline \multirow[t]{2}{*}{ C. truncatum ${ }^{\mathrm{y}}$} & & Ct_RR13_1 & Saluda, SC & 2013 \\
\hline & & Ct_RR13_2 & Saluda, SC & 2013 \\
\hline \multirow[t]{15}{*}{ C. acutatum $^{2}$} & C. nymphaeae & $\mathrm{CaPH} 40$ & Spartanburg, SC & 2004 \\
\hline & & CaCO4_35 & Unknown, SC & 2004 \\
\hline & & $\mathrm{CaPH} 44$ & Spartanburg, SC & 2004 \\
\hline & & $\mathrm{CaC} 04 \_42$ & Unknown, SC & 2004 \\
\hline & & CaCO4_59 & Unknown, SC & 2004 \\
\hline & C. fioriniae-subgroup 2 & C.2.4.2 & Unknown, GA & 2015 \\
\hline & & C.2.2.2 & Unknown, GA & 2015 \\
\hline & & C.2.3.2 & Unknown, GA & 2015 \\
\hline & & C. 3.3 & Unknown, GA & 2015 \\
\hline & & C.5.4 & Unknown, GA & 2015 \\
\hline & & C.2.1.1 & Unknown, GA & 2015 \\
\hline & & C.5.1 & Unknown, GA & 2015 \\
\hline & C. fioriniae-subgroup 1 & CaEY12_2 & Spartanburg, SC & 2004 \\
\hline & & CaEY12_1 & Spartanburg, SC & 2004 \\
\hline & & $\mathrm{CaPH} 4$ & Spartanburg, SC & 2004 \\
\hline
\end{tabular}

\footnotetext{
${ }^{x}$ Refer to Hu et al. (2015b).

${ }^{y}$ Refer to Grabke et al. (2015).

${ }^{\mathrm{z}}$ Identified by internal transcribed spacer (ITS)1-5.8S-ITS2, glyceraldehyde-3-phosphate dehydrogenase, and $\beta$-tubulin sequencing in this study.
} 
used (Hu et al. 2015b): the Tamura three-parameter model, $\gamma$ distributed (five categories), and heuristic method using SPR-extensive. The bootstrap consensus tree, inferred from 1,000 replicates, was constructed.

Fungicide sensitivity assessments in vitro. DMI sensitivity assays were based on methods developed by Miller et al. (2002). Isolates were cultured on PDA plates at $30^{\circ} \mathrm{C}$ for 5 days (C. siamense, C. fructicola, and C. truncatum isolates) and $25^{\circ} \mathrm{C}$ for 8 days (C. nymphaeae and C. fioriniae isolates) in darkness to supply inoculum. Mycelial discs (4 $\mathrm{mm}$ in diameter) from the periphery of colonies actively growing on PDA were transferred onto PDA medium containing DMI fungicides with the active ingredient at $0,0.03,0.1$, $0.3,1,3,10,30$, and $100 \mu \mathrm{g} / \mathrm{ml}$. The commercial formulations of difenoconazole, propiconazole, tebuconazole, metconazole, flutriafol, and fenbuconazole were diluted with sterilized distilled water in a series and added to autoclaved PDA medium cooled to $60^{\circ} \mathrm{C}$.

Cultures were incubated at $30^{\circ} \mathrm{C}(C$. siamense, C. fructicola, and C. truncatum $)$ and $25^{\circ} \mathrm{C}(C$. nymphaeae and C. fioriniae $)$ without supplemental lighting, and radial growth of colonies was measured when colony diameters of cultures on control dishes reached at least $50 \mathrm{~mm}$ (4 days for $C$. siamense, $C$. fructicola, and $C$. truncatum or 8 days for $C$. nymphaeae and $C$. fioriniae). The diameter of each colony was measured in two perpendicular directions and the mean diameter was adjusted by subtracting the diameter of the original plugs used for inoculation.

Fungicide sensitivity, as measured by the $50 \%$ effective concentration $\left(\mathrm{EC}_{50}\right)$ value, was calculated as described by Wong and Wilcox (2002). Briefly, the percent relative growth (RG) was calculated as (radial growth at fungicide concentration/radial growth on the nonamended check plate) $\times 100$. The $\mathrm{EC}_{50}$ value was estimated by linear regression of the probit-transformed relative inhibition (RI) value $(\mathrm{RI}=1-\mathrm{RG})$ on $\log _{10}$ transformed-fungicide concentration. The $\mathrm{EC}_{50}$ value for each isolate was calculated as the mean of the three replicates.

To measure cross-resistance between pairs of the fungicides tested, the $\log \mathrm{EC}_{50}$ values were correlated and the correlation coefficient

Table 2. GenBank accession numbers for internal transcribed spacer (ITS), glyceraldehyde-3-phosphate dehydrogenase (GAPDH), and $\beta$-tubulin (TUB2) nucleotide sequences from Colletotrichum isolates used in this study

\begin{tabular}{|c|c|c|c|c|c|}
\hline \multirow[b]{2}{*}{ Species } & \multirow[b]{2}{*}{ Culture $^{\mathrm{z}}$} & \multirow[b]{2}{*}{ Source } & \multicolumn{3}{|c|}{ GenBank accession number ${ }^{y}$} \\
\hline & & & ITS & GAPDH & $T U B 2$ \\
\hline \multirow[t]{5}{*}{$\overline{\text { Colletotrichum nymphaeae }}$} & $\mathrm{CaPH} 40$ & This study & KX066092 & KX066095 & $\overline{\mathrm{KX} 066089}$ \\
\hline & CaCO4_35 & This study & NA & NA & NA \\
\hline & $\mathrm{CaPH} 4 \overline{4}$ & This study & NA & NA & NA \\
\hline & $\mathrm{CaC} 04 \_42$ & This study & NA & NA & NA \\
\hline & CaCO4_59 & This study & NA & NA & NA \\
\hline \multirow[t]{7}{*}{ C. fioriniae-subgroup 2} & C. 2.4 .2 & This study & KX066091 & KX066094 & KX066088 \\
\hline & C.2.2.2 & This study & NA & NA & NA \\
\hline & C.2.3.2 & This study & NA & NA & NA \\
\hline & C. 3.3 & This study & NA & NA & NA \\
\hline & C.5.4 & This study & NA & NA & NA \\
\hline & C.2.1.1 & This study & NA & NA & NA \\
\hline & C.5.1 & This study & NA & NA & NA \\
\hline \multirow{3}{*}{ C. fioriniae-subgroup 1} & CaEY12_1 & This study & KX066093 & KX066096 & KX066090 \\
\hline & CaEY12_2 & This study & NA & NA & NA \\
\hline & $\mathrm{CaPH} 4$ & This study & NA & NA & NA \\
\hline C. nymphaeae & CBS 100064 & GenBank & JQ948224 & JQ948554 & JQ949875 \\
\hline C. guajavae & IMI 350838, CPC 18893 & GenBank & JQ948270 & JQ948600 & JQ949921 \\
\hline C. scovillei & CBS 126529 & GenBank & JQ948267 & JQ948597 & JQ949918 \\
\hline C. chrysanthemi & IMI 36454,CPC 18930 & GenBank & JQ948273 & JQ948603 & JQ949924 \\
\hline C. walleri & CBS 125472 & GenBank & JQ948275 & JQ948605 & JQ949926 \\
\hline C. simmondsii & CBS 294.67 & GenBank & JQ948277 & JQ948607 & JQ949928 \\
\hline C. brisbanense & CBS 292.67 & GenBank & JQ948291 & JQ948621 & JQ949942 \\
\hline C. paxtonii & CBS 502.97 & GenBank & JQ948286 & JQ948616 & JQ949937 \\
\hline C. sloanei & IMI 364297,CPC18929 & GenBank & JQ948287 & JQ948617 & JQ949938 \\
\hline C. indonesiense & CBS 127551 & GenBank & JQ948288 & JQ948618 & JQ949939 \\
\hline C. laticiphllum & CBS 112989 & GenBank & JQ948289 & JQ948619 & JQ949940 \\
\hline C. lupini & IMI 35126,CPC 18896 & GenBank & JQ948177 & JQ948507 & JQ949828 \\
\hline C. melonis & CBS 159.84 & GenBank & JQ948194 & JQ948524 & JQ949845 \\
\hline C. tamarilloi & CBS 129814 & GenBank & JQ948184 & JQ948514 & JQ949835 \\
\hline C. limetticola & CBS 114.14 & GenBank & JQ948193 & JQ948523 & JQ949844 \\
\hline C. acutatum & IMI 223120, CPC 18870 & GenBank & JQ948353 & JQ948684 & JQ950004 \\
\hline C. fioriniae-subgroup 1 & CBS 125396 & GenBank & JQ948299 & JQ948629 & JQ949950 \\
\hline C. fioriniae-subgroup 2 & CBS 119292 & GenBank & JQ948313 & JQ948643 & JQ949964 \\
\hline C. salicis & CBS 129972 & GenBank & JQ948466 & JQ948797 & JQ950117 \\
\hline C. johnstonii & IMI 357027 & GenBank & JQ948443 & JQ948774 & JQ950094 \\
\hline C. pyricola & CBS 128531 & GenBank & JQ948445 & JQ948776 & JQ950096 \\
\hline C. godetiae & CBS 796.72 & GenBank & JQ948407 & JQ948738 & JQ950058 \\
\hline C. australe & CBS 116478 & GenBank & JQ948455 & JQ948786 & JQ950106 \\
\hline C. acerbum & CBS 128530 & GenBank & JQ948459 & JQ948790 & JQ950110 \\
\hline C. rhombiforme & CBS 129953 & GenBank & JQ948457 & JQ948788 & JQ950108 \\
\hline C. kinghornii & CBS 198.35 & GenBank & JQ948454 & JQ948785 & JQ950105 \\
\hline C. phormii & CBS 118201 & GenBank & JQ948449 & JQ948780 & JQ950100 \\
\hline C. orchidophilum & CBS 631.80 & GenBank & JQ948152 & JQ948482 & JQ949803 \\
\hline
\end{tabular}


was estimated for each pair. Statistical analyses were performed using SPSS software (release 13.0; SPSS Inc., Chicago). We did not include $C$. truncatum data in our sensitivity and cross-resistance analyses because this species is a rather uncommon pathogen of peach and the two isolates available were collected from the same orchard and, thus, do not reflect sufficient intraspecies variation.

\section{Results}

Phylogenetic tree analysis. Phylogenetic analysis was conducted based on ITS, GAPDH, and TUB2 sequences of 15 isolates collected for this study and 27 previously characterized reference strains (Table 2). The topologies of the phylogenetic trees were constructed with the MP and ML methods and were largely concordant with each other, indicating that the evolutionary relationship of the tested isolates was statistically supported (Fig. 1A and 1B). There were 1,094 nucleotide positions included in the final dataset, 231 of which were parsimony informative. The eight isolates from South Carolina, collected in 2004, clustered into two groups. CaPH44, CaPH40, CaCO4_42, CaC04_59, and CaCO4_35 clustered with $C$. nymphaeae reference strain CBS 100064 . This clade was most closely related to four reference isolates of $C$. scovillei, C. chrysanthemi, C. gurajavae, and C. walleri. Isolates CaEY12_1, CAEY12_2, and $\mathrm{CaPH} 4$ formed a clade with $C$. fioriniae-subgroup 1 reference strain CBS125396. Isolates collected from Georgia in 2015 formed into another clade with $C$. fioriniae-subgroup 2 reference strain CBS 119292. ITS, GAPDH, and TUB2 nucleotide sequences were deposited in GenBank (Table 2).

Efficacy of DMI fungicides against Colletotrichum spp. The sensitivity of isolates from six Colletotrichum spp., including C. fructicola, C. siamense, $C$. truncatum, C. nymphaeae, C. fioriniaesubgroup 1, and $C$. fioriniae-subgroup 2 (Table 1), to six DMI fungicides was determined on PDA (Table 3). $C$. fructicola and $C$. siamense isolates were generally sensitive to all six DMI fungicides (Table 3), with
$\mathrm{EC}_{50}$ values of 0.2 to $13.1 \mu \mathrm{g} / \mathrm{ml}$. The $\mathrm{EC}_{50}$ values also indicated that C. truncatum and $C$. nymphaeae isolates were resistant to flutriafol and fenbuconazole $\left(\mathrm{EC}_{50}\right.$ values $\left.>100 \mu \mathrm{g} / \mathrm{ml}\right)$. Also, C. truncatum displayed reduced sensitivity to tebuconazole and metconazole (Table 3), with $\mathrm{EC}_{50}$ values of 54.7 and $16.6 \mu \mathrm{g} / \mathrm{ml}$, respectively. Although C. fioriniae-subgroup 2 isolates were closely related to $C$. fioriniaesubgroup 1 from a phylogenetic perspective, significant differences in sensitivity to DMI fungicides were observed between these two species (Table 3). Overall, $C$. fioriniae-subgroup 1 isolates were more sensitive to all six DMI fungicides than $C$. fioriniae-subgroup 2 isolates. For example, the mean $\mathrm{EC}_{50}$ values of $C$. fioriniae-subgroup 1 to flutriafol and fenbuconazole were 2.1 and $0.4 \mu \mathrm{g} / \mathrm{ml}$, respectively, whereas those of $C$. fioriniae-subgroup 2 isolates were 16.2 and $5.2 \mu \mathrm{g} / \mathrm{ml}$, respectively (Table 3 ).

Based on $\mathrm{EC}_{50}$ values, difenoconazole and propiconazole were most effective against the six Colletotrichum spp. used in this study (Fig. 2). Tebuconazole and metconazole were effective against C. fructicola, C. siamense, C. nymphaeae, C. fioriniae-like, and C. fioriniae but not against the C. truncatum (Fig. 2). Both flutriafol and fenbuconazole at $100 \mu \mathrm{g} / \mathrm{ml}$ showed no suppressive activity against mycelium growth of $C$. nymphaeae and $C$. truncatum on PDA medium (Fig. 2). Moreover, the $\mathrm{EC}_{50}$ values of the six species against flutriafol were higher than other DMI fungicides (Fig. 2).

Cross-sensitivity to DMI fungicides among Colletotrichum isolates. Cross sensitivity to DMI fungicides varied among Colletotrichum spp. (Table 4). Correlation coefficients between difenoconazolepropiconazole and difenoconazole-fenbuconazole ranged from 0.7 to $1(P<0.05)$, indicating high association between sensitivities for these fungicides. For $C$. siamense and $C$. fructicola isolates, strong correlations were also found between flutriafol and metconazole, with coefficient of determination $\left(R^{2}\right)$ values of 0.9 for both $(P<0.05)$. For $C$. nymphaeae isolates, the correlations between difenoconazole, flutriafol, fenbuconazole, and propiconazole were
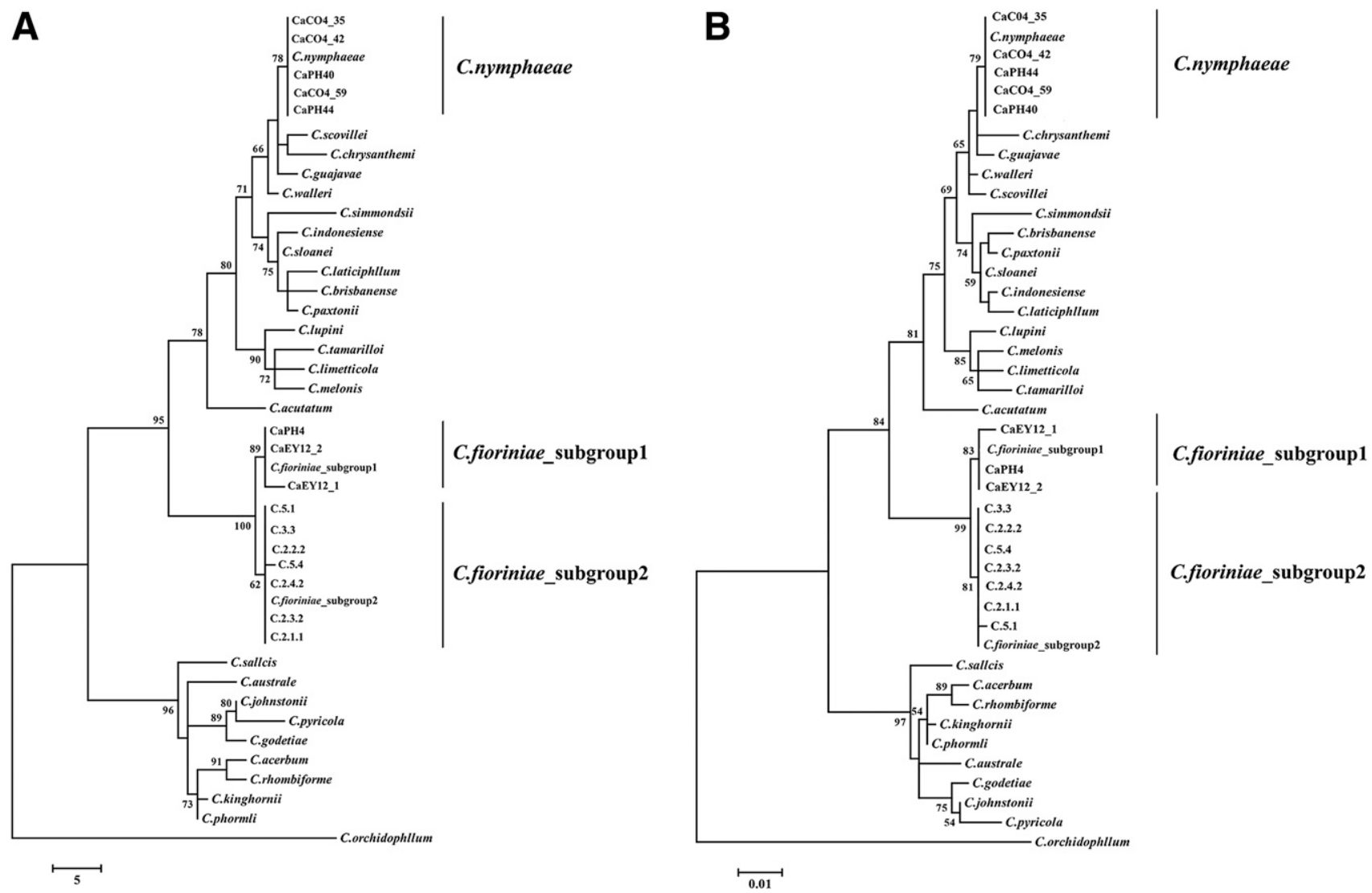

Fig. 1. Phylogeny of Colletotrichum isolates from peach and one outgroup species (Colletotrichum orchidophilum). A, Maximum parsimony and B, maximum-likelihood trees inferred from the data set containing the combined DNA sequences of internal transcribed spacer (ITS), glyceraldehyde-3-phosphate dehydrogenase (GAPDH), and $\beta$-tubulin (TUB2), with 1,094 characters, 231 of with were informative. Numbers labeled at each node indicate bootstrap values (\%) from 1,000 replicates. 
strong, with $R^{2}$ of 0.8 to $1(P<0.05)$. For other fungicide combinations, the correlation coefficients were lower, with $R^{2}$ values of 0.1 to $0.6(P>0.05)$. For $C$. fioriniae-subgroup 1 , the correlation in sensitivities was strong between propiconazole and tebuconazole, metconazole, and difenoconazole; between difenoconazole and tebuconazole, metconazole, flutriafol, and fenbuconazole; and also between flutriafol and metconazole $\left(R^{2}\right.$ values of 0.7 to $\left.1.0, P<0.05\right)$. For $C$. fioriniaesubgroup 2 , strong relationships were found in all fungicide interactions except for fenbuconazole and propiconazole.

\section{Discussion}

Multilocus molecular phylogenetic analysis conducted on the basis of ITS, ACT, TUB2, chitin synthase (CHS-1), GAPDH, and histone 3 (HIS3) gene sequences delimited 31 species within the $C$. acutatum species complex (Damm et al. 2012). Further analysis determined that all subclades can be recognized with TUB2 and GAPDH sequences alone (Damm et al. 2012). In our study, the combined sequence data of ITS, TUB2, and $G 3 P D H$ clearly identified $C$. acutatum isolates to belong to either $C$. nymphaeae or $C$. fioriniae. With the discovery of these additional two $C$. acutatum species, the total number of Colletotrichum spp. known to cause anthracnose of peach in the Southeast climbed to five.

Both $C$. nymphaeae and $C$. fioriniae do have a wide host range. C. nymphaeae is a pathogen of strawberry fruit (Damm et al. 2012) but can also infect kadsura, gentianaceae, loquat, flowering plants, celery, apple, hoary stock, parsley, plum, peach, mung bean (Sato and Moriwaki 2013), and blueberry (MacKenzie et al. 2009). C. fioriniae was isolated from almond, apple, avocado, mango, nectarine (Guerber et al. 2003), and blueberry (MacKenzie et al. 2009).

Within C. fioriniae, there is evidence of heterogeneity, because two subclades were apparent in the phylogenetic analysis of this study and one previous study (Damm et al. 2012). All of the isolates collected in 2015 from Georgia formed into the same clade of $C$. fioriniaesubgroup 2. Isolates of $C$. fioriniae subgroup 1 were collected from South Carolina. Prior to this study, phenotypical differences between the two subgroups were unknown. The sensitivity of subgroup 1 and 2 to difenoconazole, propiconazole, flutriafol, and fenbuconazole were significantly different (Table 3 ). Isolates from subgroup 2 were more sensitive to polyoxin-D ( $7 \mu \mathrm{g} / \mathrm{ml}$ average) compared with subgroup $1\left(\mathrm{EC}_{50}\right.$ values $\left.>100 \mu \mathrm{g} / \mathrm{ml}\right)$ on malt extract agar medium $(P<$ 0.05 , data not shown). However, neither bootstrap support nor Bayesian probability values were sufficiently high to divide them into different species, and strains from different hosts and countries did not cluster together (Damm et al. 2012).

Species of Colletotrichum may exhibit striking differences to fungicides. For example, most wild-type $C$. gloeosporioides isolates are highly sensitive to benomyl and thiophanate-methyl, which is why the latter is still recommended for the control of anthracnose crown rot (Brannen and Smith 2014). However, C. acutatum is inherently resistant to benomyl and other MBC fungicides (Adaskaveg and Hartin 1997; Peres et al. 2002, 2004; Talhinhas et al. 2002, 2005). In our study, C. truncatum exhibited exceptional resilience to tebuconazole, metconazole, flutriafol, and fenbuconazole. Luckily, this species is an extremely rare pathogen of peach. To the best of our knowledge, the sensitivity of plant-pathogenic $C$. truncatum to DMI fungicides has never been investigated and, thus, we are unable to compare our results with other studies. However, a case of $C$. truncatum species complex fungal keratitis and endophthalmitis has been reported in an immunocompetent human male in whom oral triazole antifungals were contraindicated (Squissato et al. 2015). Similar to our study, $C$. truncatum showed high minimum inhibitory concentrations and probable resistance to triazoles used in human medicine, including voriconazole, ketoconazole, itraconazole, and miconazole.

Table 3. Mean $50 \%$ effective concentration $\left(\mathrm{EC}_{50}\right)$ values of Colletotrichum isolates to demethylation inhibitor fungicides

\begin{tabular}{|c|c|c|c|c|c|c|}
\hline \multirow[b]{2}{*}{ Species $^{\mathbf{z}}$} & \multicolumn{6}{|c|}{ Mean $\mathrm{EC}_{50}$ values $(\mu \mathrm{g} / \mathrm{ml})^{y}$} \\
\hline & Difen & Propi & Tebuco & Metco & Flutri & Fenbu \\
\hline Colletotrichum fructicola & $0.9 \pm 0.5 \mathrm{~b}$ & $0.2 \pm 0.1 \mathrm{c}$ & $0.8 \pm 0.1 \mathrm{~b}$ & $0.8 \pm 0.4 \mathrm{~b}$ & $13.1 \pm 12.0 \mathrm{ab}$ & $3.3 \pm 1.3 \mathrm{a}$ \\
\hline C. siamense & $0.3 \pm 0.3 \mathrm{c}$ & $0.2 \pm 0.1 \mathrm{c}$ & $1.1 \pm 0.4 \mathrm{~b}$ & $0.6 \pm 0.2 b$ & $4.1 \pm 0.6 \mathrm{~b}$ & $3.4 \pm 2.3 \mathrm{a}$ \\
\hline C. truncatum & $2.7 \pm 0.3 \mathrm{a}$ & $2.4 \pm 0.5 \mathrm{ab}$ & $54.7 \pm 15.0 \mathrm{a}$ & $16.6 \pm 0.3 \mathrm{a}$ & $>100$ & $>100$ \\
\hline C. nymphaeae & $1.3 \pm 0.3 \mathrm{~b}$ & $2.5 \pm 0.7 \mathrm{a}$ & $0.8 \pm 0.4 \mathrm{~b}$ & $1.4 \pm 0.9 \mathrm{~b}$ & $>100$ & $>100$ \\
\hline C. fioriniae-subgroup 2 & $0.5 \pm 0.1 \mathrm{~b}$ & $1.2 \pm 0.7 \mathrm{~b}$ & $0.5 \pm 0.1 \mathrm{~b}$ & $0.5 \pm 0.4 \mathrm{~b}$ & $16.2 \pm 8.5 \mathrm{a}$ & $5.2 \pm 4.2 \mathrm{a}$ \\
\hline C. fioriniae-subgroup 1 & $0.2 \pm 0.2 \mathrm{c}$ & $0.3 \pm 0.2 \mathrm{c}$ & $0.2 \pm 0.1 \mathrm{~b}$ & $0.03 \pm 0.05 \mathrm{~b}$ & $2.1 \pm 1.3 \mathrm{~b}$ & $0.4 \pm 0.3 \mathrm{~b}$ \\
\hline
\end{tabular}

${ }^{\mathrm{y}}$ Mean values within columns followed by the same letter are equivalent based on Fisher's protected least significant difference $(P=0.05)$. Difen $=$ difenoco-

nazole Propi $=$ propiconazole, Tebuco $=$ tebuconazole, Metco $=$ metconazole, Flutri $=$ flutriafol, and Fenbu $=$ fenbuconazole .

${ }^{\mathrm{z}}$ Mean and standard error from the average of three isolates for each species, except $C$. truncatum, for which only two isolates were collected.

Table 4. Cross-sensitivity between demethylation inhibitor fungicides for Colletotrichum siamense, C. fructicola, C. nymphaeae, and C. fioriniae

\begin{tabular}{|c|c|c|c|c|c|}
\hline \multirow[b]{2}{*}{ Interaction $^{\mathrm{z}}$} & \multicolumn{5}{|c|}{$R^{2 y}$} \\
\hline & C. siamense & C. fructicola & C. nymphaeae & C. fioriniae-subgroup 1 & C. fioriniae-subgroup 2 \\
\hline Tebuco-Propi & 0.6 & 0.5 & 0.1 & $1^{*}$ & $1 *$ \\
\hline Metco-Tebuco & $0.7 *$ & 0.1 & 0.6 & 0.6 & $1 *$ \\
\hline Metco-Propi & 0.1 & 0.2 & 0.2 & $0.7^{*}$ & $0.9^{*}$ \\
\hline Difen-Tebuco & 0.2 & $0.9^{*}$ & 0.1 & $0.7^{*}$ & $0.9^{*}$ \\
\hline Difen-Propi & $0.8^{*}$ & $0.9^{*}$ & $1^{*}$ & $0.8^{*}$ & $0.8^{*}$ \\
\hline Difen-Metco & 0.1 & 0 & 0.2 & $1^{*}$ & $1 *$ \\
\hline Flutri-Tebuco & 0.3 & 0.3 & 0.4 & 0.3 & $1^{*}$ \\
\hline Flutri-Propi & 0 & 0.1 & 0.8 & 0.4 & $0.9^{*}$ \\
\hline Flutri-Metco & $0.9 *$ & $0.9 *$ & 0 & $0.9 *$ & $1^{*}$ \\
\hline Flutri-Difen & 0.2 & 0 & $0.8^{*}$ & $0.8^{*}$ & $1^{*}$ \\
\hline Fenbu-Tebuco & 0 & 0.3 & 0.3 & 0.6 & 0.6 \\
\hline Fenbu-Propi & 0.3 & $0.9 *$ & $0.8^{*}$ & 0.5 & 0.4 \\
\hline Fenbu-Metco & 0.4 & 0.4 & 0 & 0 & $0.8^{*}$ \\
\hline Fenbu-Difen & $0.7 *$ & $0.7 *$ & $0.8^{*}$ & $0.9^{*}$ & $0.9^{*}$ \\
\hline Fenbu-Flutri & $0.8^{*}$ & 0.2 & $1 *$ & 0.1 & $0.7 *$ \\
\hline
\end{tabular}

${ }^{y}$ Coefficient of determination $\left(R^{2}\right)$ determined by comparison of log $50 \%$ effective concentration values for each fungicide from the individual Colletotrichum spp.; an asterisk $(*)$ indicates correlation coefficient significant at $P=0.05$.

${ }^{\mathrm{z}}$ Difen $=$ difenoconazole Propi $=$ propiconazole, Tebuco $=$ tebuconazole, Metco $=$ metconazole, Flutri $=$ flutriafol, and Fenbu $=$ fenbuconazole. 
Isolates of the five Colletotrichum spp. included in this study revealed $\mathrm{EC}_{50}$ values of 0.2 to $2.7 \mu \mathrm{g} / \mathrm{ml}$ for difenoconazole and propiconazole, 0.03 to $54.7 \mu \mathrm{g} / \mathrm{ml}$ for tebuconazole and metconazole, and 0.4 to more than $100 \mu \mathrm{g} / \mathrm{ml}$ for flutriafol and fenbuconazole. These values indicate that the sensitivity to difenoconazole and propiconazole of Colletotrichum spp. was consistently high. Differences in intrinsic activities between four DMI fungicides were also found in C. cereale (Wong and Wilcox 2002). Regardless of previous exposure to DMI fungicides, $C$. cereale isolates were most sensitive to tebuconazole and propiconazole, less sensitive to myclobutanil, and least sensitive to triadimefon. The authors reported that the in vitro intrinsic activity corresponded to the performance of these DMI fungicides for anthracnose control in the field (Towers et al. 2003). Our study showed higher $\mathrm{EC}_{50}$ values to fenbuconazole for almost all the Colletotrichum isolates (Table 3), which indicated that fenbuconazole should not be relied on for the control of Colletotrichum spp. This was in agreement with a previous study, where fenbuconazole was found to result in higher anthracnose fruit rot incidence caused by $C$. gloeosporioides isolates in cranberry (Wells et al. 2014). Practical implications of differential activity of DMI fungicides to target organisms was discussed previously (Erickson and Wilcox 1997; Ypema et al. 1997). DMI fungicides with lower $\mathrm{EC}_{50}$ values provided better protection from Uncinula necator (syn. Erysiphe necator) compared with DMI fungicides with higher $\mathrm{EC}_{50}$ values in field trials (Erickson and Wilcox 1997; Ypema et al. 1997). Based on the $\mathrm{EC}_{50}$ values determined in this study, difenoconazole and propiconazole may provide better control efficacy in the field compared with tebuconazole and metconazole against most Colletotrichum spp. However, this would need to be verified in field studies. Our data also imply that fenbuconazole and flutriafol may have the lowest control efficacy and, thus, may not provide sufficient protection from peach anthracnose.

Correlation coefficients among difenoconazole, propiconazole, tebuconazole, metconazole, flutriafol, and fenbuconazole varied for different Colletotrichum spp. (Table 4). This is consistent with results reported for other pathogens such as Sclerotinia homoeocarpa (Hsiang et al. 1997; Miller et al. 2002), Cercospora beticola (Karaoglanidis and Thanassoulopoulos 2003), U. necator (Erickson and Wilcox 1997; Ypema et al. 1997), Monilinia fructicola (Holb and Schnabel 2007), and Rhynchosporium secalis (Kendall et al. 1993)

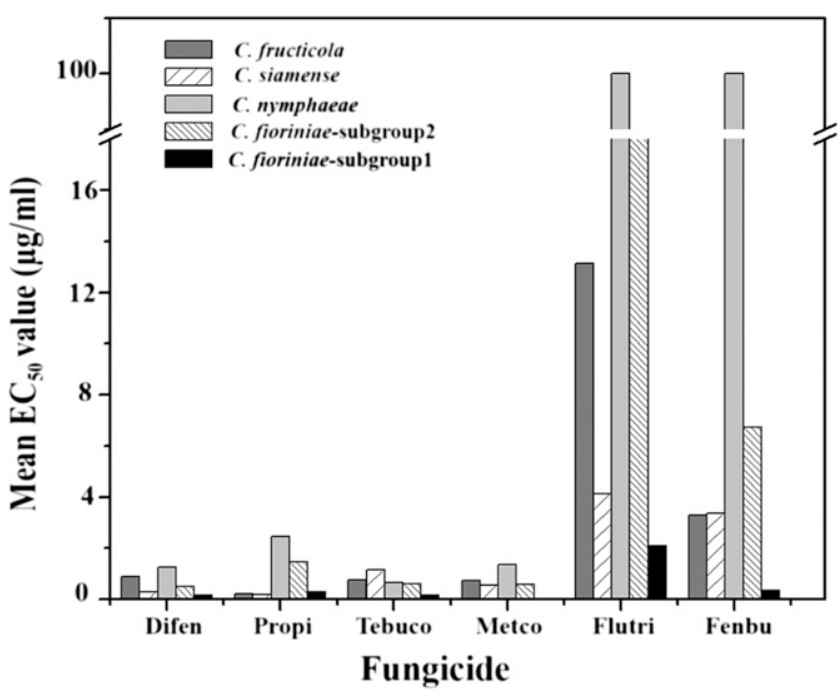

Fig. 2. The $50 \%$ effective concentration $E_{50}$ values of Colletotrichum spp. for difenoconazole (Difen), propiconazole (Propi), tebuconazole (Tebuco), metconazole (Metco), flutriafol (Flutri), and fenbuconazole (Fenbu). Colletotrichum fructicola was represented by isolates Cg_RR12_3, Cg_RR12_1, and Cg_SE12_1; C. siamense was represented by isolates $\mathrm{Cg}$ EEy12_1, $\mathrm{Cg}$ _OD13_2, and $\mathrm{Cg}$ Ey12_10; $\mathrm{C}$. truncatum was represented by isolates Ct_RR13_1 and Ct_RR13_2; $C$. nymphaeae was represented by isolates $\mathrm{CaPH} 40, \mathrm{CaCO} 4 \_35$, and $\mathrm{CaPH} 44 ; \mathrm{C}$. fioriniaesubgroup 2 was represented by isolates C.2.4.2, C.2.3.2, and C.2.2.2; and C. fioriniae-subgroup 1 was represented by isolates CaEY12_2, CaEY12_1, and CaPH4. to DMI fungicides. Low correlation coefficients in some DMI fungicide interactions may indicate the resistance to be a multigenetic trait or may indicate the resistance to be a single gene trait with different mutations involved, each of which may confer resistance to specific DMI (Fraaije et al. 2007). Some correlation coefficient among the DMI were as low as 0.1 and some as high as 1 , indicating that cross-resistance relationships among DMI can vary dramatically, and that no single model of cross-resistance among DMI is appropriate among all Colletotrichum spp., which has also been demonstrated in Pyrenophora teres (Peever and Milgroom 1993) and U. necator (Erickson and Wilcox 1997).

Our study indicates that pathogens causing peach anthracnose display differential sensitivity to DMI fungicides; however, the molecular basis is unknown. One potential mechanism of resistance to DMI fungicides involves point mutations within the substrate recognition site of the P450 demethylation inhibitor (CYP51) genes. Examples include the pathogenic fungi U. necator (Délye et al. 1997), Blumeria graminis (Wyand and Brown 2005), E. graminis (Délye et al. 1998), and Candida albicans (Favre et al. 1999; Löffler et al. 1997; Marichal et al. 1999; Sanglard et al. 1998), which exhibited alterations in the sequence of CYP51 genes in resistant isolates. Increased expression of the CYP51 gene is another potential mechanism of DMI fungicide resistance, which has been reported in Bulbophyllum jaapii (Ma et al. 2006), Penicillium digitatum (Ghosoph et al. 2007; Hamamoto et al. 2000; Sun et al. 2011), M. fructicola (Luo and Schnabel 2008), Venturia inaequalis (Schnabel and Jones 2001), Cercospora beticola (Nikou et al. 2009), and Mycosphaerella graminicola (Cools et al. 2012). Expression of ABC transporters was also reported in resistant strains of Aspergillus nidulas and P. digitatum (Del Sorbo et al. 1997; Nakaune et al. 1998).

This study indicates that at least five Colletotrichum spp. occur on peach fruit in South Carolina and Georgia and that Colletotrichum nymphaeae and C. truncatum are inherently resistant to DMI fungicides. Thus, the importance for practitioners to know the species involved in causing anthracnose disease was underscored by our study. DMI fungicides primarily used for preharvest brown rot control that also have high intrinsic activity to Colletotrichum spp. may increase control success for anthracnose disease management if integrated into the summer spray program. However, this would need to be verified in field trials.

\section{Acknowledgments}

Technical contribution number 6458 of the Clemson University Experiment Station. This material is based upon work supported by the United States Department of Agriculture National Institute of Food and Agriculture under project number SC-1700501, the South Carolina Peach Council, the Chinese Academy of Sciences, and the South Carolina Department of Agriculture Specialty Crop Block Grant Program.

\section{Literature Cited}

Adaskaveg, J. 2000. Occurrence and management of anthracnose epidemics caused by Colletotrichum species on tree fruit crops in California. Pages 317-336 in: Colletotrichum: Host Specificity, Pathology and Host-Pathogen Interaction. D. Prusky, S. Freeman, and M. B. Dickman, eds. American Phytopathological Society, St. Paul, MN.

Adaskaveg, J., and Hartin, R. 1997. Characterization of Colletotrichum acutatum isolates causing anthracnose of almond and peach in California. Phytopathology 87:979-987.

Bernstein, B., Zehr, E., Dean, R. A., and Shabi, E. 1995. Characteristics of Colletotrichum from peach, apple, pecan, and other hosts. Plant Dis. 79:478-482.

Brannen, P., and Smith, P. 2014. 2015 Southeast Regional Strawberry Integrated Pest Management Guide. Online publication. http://www.smallfruits.org/ SmallFruitsRegGuide/

Cools, H. J., Bayon, C., Atkins, S., Lucas, J. A., and Fraaije, B. A. 2012. Overexpression of the sterol $14 \alpha$-demethylase gene (MgCYP51) in Mycosphaerella graminicola isolates confers a novel azole fungicide sensitivity phenotype. Pest Manage. Sci. 68:1034-1040.

Damm, U., Cannon, P., Woudenberg, J., and Crous, P. 2012. The Colletotrichum acutatum species complex. Stud. Mycol. 73:37-113.

Del Sorbo, G., Andrade, A. C., Van Nistelrooy, J., Van Kan, J., Balzi, E., and De Waard, M. 1997. Multidrug resistance in Aspergillus nidulans involves novel ATP-binding cassette transporters. Mol. Gen. Genet. 254:417-426.

Délye, C., Bousset, L., and Corio-Costet, M.-F. 1998. PCR cloning and detection of point mutations in the eburicol 14a-demethylase (CYP51) gene from Erysiphe graminis f. sp. hordei, a "recalcitrant" fungus. Curr. Genet. 34:399-403. 
Délye, C., Laigret, F., and Corio-Costet, M.-F. 1997. A mutation in the 14 alphademethylase gene of Uncinula necator that correlates with resistance to a sterol biosynthesis inhibitor. Appl. Environ. Microbiol. 63:2966-2970.

Erickson, E. O., and Wilcox, W. F. 1997. Distributions of sensitivities to three sterol demethylation inhibitor fungicides among populations of Uncinula necator sensitive and resistant to triadimefon. Phytopathology 87:784-791.

Favre, B., Didmon, M., and Ryder, N. S. 1999. Multiple amino acid substitutions in lanosterol $14 \alpha$-demethylase contribute to azole resistance in Candida albicans. Microbiology 145:2715-2725.

Fraaije, B. A., Cools, H. J., Kim, S.-H., Motteram, J., Clark, W. S., and Lucas, J. A. 2007. A novel substitution I381V in the sterol $14 \alpha$-demethylase (CYP51) of Mycosphaerella graminicola is differentially selected by azole fungicides. Mol. Plant Pathol. 8:245-254.

Gardes, M., and Bruns, T. D. 1993. ITS primers with enhanced specificity for basidiomycetes-application to the identification of mycorrhizae and rusts. Mol. Ecol. 2:113-118.

Ghosoph, J. M., Schmidt, L. S., Margosan, D. A., and Smilanick, J. L. 2007. Imazalil resistance linked to a unique insertion sequence in the PdCYP51 promoter region of Penicillium digitatum. Postharvest Biol. Technol. 44:9-18.

Gopinath, K., Radhakrishnan, N., and Jayaraj, J. 2006. Effect of propiconazole and difenoconazole on the control of anthracnose of chilli fruits caused by Colletotrichum capsici. Crop Prot. 25:1024-1031.

Grabke, A., Williamson, M., Henderson, G., and Schnabel, G. 2015. First report of anthracnose on peach fruit caused by Colletotrichum truncatum in South Carolina. Plant Dis. 99:806-814.

Guerber, J. C., Liu, B., Correll, J. C., and Johnston, P. R. 2003. Characterization of diversity in Colletotrichum acutatum sensu lato by sequence analysis of two gene introns, mtDNA and intron RFLPs, and mating compatibility. Mycologia 95:872-895.

Hamamoto, H., Hasegawa, K., Nakaune, R., Lee, Y. J., Makizumi, Y., Akutsu, K., and Hibi, T. 2000. Tandem repeat of a transcriptional enhancer upstream of the sterol 14 $\alpha$-demethylase gene (CYP51) in Penicillium digitatum. Appl. Environ. Microbiol. 66:3421-3426.

Holb, I. J., and Schnabel, G. 2007. Differential effect of triazoles on mycelial growth and disease measurements of Monilinia fructicola isolates with reduced sensitivity to DMI fungicides. Crop Prot. 26:753-759.

Horton, D., Brannen, P., Bellinger, B., Lockwood, D., and Ritchie, D. 2016. Southern peach, nectarine and plum pest management and culture guide. Bulletin 1171, University of Georgia Cooperative Extension Service, College of Agricultural and Environmental Sciences, Athens, GA.

Hsiang, T., Yang, L., and Barton, W. 1997. Baseline sensitivity and crossresistance to demethylation-inhibiting fungicides in Ontario isolates of Sclerotinia homoeocarpa. Eur. J. Plant Pathol. 103:409-416.

Hu, M.-J., Grabke, A., Dowling, M. E., Holstein, H. J., and Schnabel, G. 2015a. Resistance in Colletotrichum siamense from peach and blueberry to thiophanatemethyl and azoxystrobin. Plant Dis. 99:806-814.

Hu, M.-J., Grabke, A., and Schnabel, G. 2015b. Investigation of the Colletotrichum gloeosporioides species complex causing peach anthracnose in South Carolina. Plant Dis. 99:797-805.

Jones, A., and Ehret, G. 1976. Isolation and characterization of benomyl-tolerant strains of Monilinia fructicola on stone fruit crops produced in Michigan, fungal diseases. Plant Dis. Rep. 60:765-769.

Karaoglanidis, G., and Thanassoulopoulos, C. 2003. Cross-resistance patterns among sterol biosynthesis inhibiting fungicides (SBIs) in Cercospora beticola. Eur. J. Plant Pathol. 109:929-934.

Kendall, S. J., Hollomon, D., Cooke, L. R., and Jones, D. 1993. Changes in sensitivity to DMI fungicides in Rhynchosporium secalis. Crop Prot. 12:357-362.

Kim, W.-G., and Hong, S.-K. 2008. Occurrence of anthracnose on peach tree caused by Colletotrichum species. Plant Pathol. J. 24:80-83.

Larkin, M. A., Blackshields, G., Brown, N., Chenna, R., McGettigan, P. A., McWilliam, H., Valentin, F., Wallace, I. M., Wilm, A., and Lopez, R. 2007. Clustal W and Clustal X version 2.0. Bioinformatics 23:2947-2948.

Löffler, J., Kelly, S. L., Hebart, H., Schumacher, U., Lass-Flörl, C., and Einsele, H. 1997. Molecular analysis of cyp51 from fluconazole-resistant Candida albicans strains. FEMS Microbiol. Lett. 151:263-268.

Luo, C.-X., and Schnabel, G. 2008. The cytochrome P450 lanosterol 14 $\alpha$-demethylase gene is a demethylation inhibitor fungicide resistance determinant in Monilinia fructicola field isolates from Georgia. Appl. Environ. Microbiol. 74:359-366.

Ma, Z., Proffer, T. J., Jacobs, J. L., and Sundin, G. W. 2006. Overexpression of the $14 \alpha$-demethylase target gene (CYP51) mediates fungicide resistance in Blumeriella jaapii. Appl. Environ. Microbiol. 72:2581-2585.

MacKenzie, S., Peres, N. A., Barquero, M., Arauz, L., and Timmer, L. 2009. Host range and genetic relatedness of Colletotrichum acutatum isolates from fruit crops and leatherleaf fern in Florida. Phytopathology 99:620-631.

Marichal, P., Koymans, L., Willemsens, S., Bellens, D., Verhasselt, P., Luyten, W., Borgers, M., Ramaekers, F. C., Odds, F. C., and Bossche, H. V. 1999. Contribution of mutations in the cytochrome P450 14 $\alpha$-demethylase (Erg 11p, Cyp51p) to azole resistance in Candida albicans. Microbiology 145:2701-2713.

Michailides, T., Ogawa, J., and Opgenorth, D. 1987. Shift of Monilinia spp. and distribution of isolates sensitive and resistant to benomyl in California prune and apricot orchards. Plant Dis. 71:893-896.

Miller, G. L., Stevenson, K. L., and Burpee, L. L. 2002. Sensitivity of Sclerotinia homoeocarpa isolates to propiconazole and impact on control of dollar spot. Plant Dis. 86:1240-1246.
Nakaune, R., Adachi, K., Nawata, O., Tomiyama, M., Akutsu, K., and Hibi, T. 1998. A novel ATP-binding cassette transporter involved in multidrug resistance in the phytopathogenic fungus Penicillium digitatum. Appl. Environ. Microbiol. 64:3983-3988.

Nikou, D., Malandrakis, A., Konstantakaki, M., Vontas, J., Markoglou, A., and Ziogas, B. 2009. Molecular characterization and detection of overexpressed C-14 alpha-demethylase-based DMI resistance in Cercospora beticola field isolates. Pestic. Biochem. Physiol. 95:18-27.

Ogawa, J. M., Manji, B. T., Bostock, R. M., Canez, V. M., and Bose, E. A. 1984 Detection and characterization of benomyl-resistant Monilinia laxa on apricots. Plant Dis. 68:29-31.

Ogawa, J. M., Zehr, E. I., Bird, G. W., Ritchie, D. F., Uriu, K., and Uyemoto, J. K 1995. Compendium of Stone Fruit Diseases. American Phytopathological Society, St. Paul, MN.

Peever, T. L., and Milgroom, M. G. 1993. Genetic correlations in resistance to sterol biosynthesis-inhibiting fungicides in Pyrenophora teres. Phytopathology 83:1076-1082.

Peres, N., Souza, N., Peever, T., and Timmer, L. 2004. Benomyl sensitivity of isolates of Colletotrichum acutatum and C. gloeosporioides from citrus. Plant Dis. 88:125-130.

Peres, N., Souza, N., Zitko, S., and Timmer, L. 2002. Activity of benomyl for control of postbloom fruit drop of citrus caused by Colletotrichum acutatum. Plant Dis. 86:620-624.

Ramsey, G., Smith, M., and Heiberg, B. 1951. Anthracnose of peaches. Phytopathology 41:447-455.

Sanglard, D., Ischer, F., Koymans, L., and Bille, J. 1998. Amino acid substitutions in the cytochrome P-450 lanosterol $14 \alpha$-demethylase (CYP51A1) from azole-resistant Candida albicans clinical isolates contribute to resistance to azole antifungal agents. Antimicrob. Agents Chemother. 42 241-253.

Sato, T., and Moriwaki, J. 2013. Molecular re-identification of strains in NIAS genebank belonging to phylogenetic groups A2 and A4 of the Colletotrichum acutatum species complex. Microbiol. Cult. Collect. 29:13-23.

Schnabel, G., Chai, W., and Cox, K. D. 2006. Identifying and characterizing summer diseases on 'Babygold' peach in South Carolina. Online publication. Plant Health Prog. doi:10.1094/PHP-2006-0301-01-RS

Schnabel, G., and Jones, A. L. 2001. The $14 \alpha$-demethylasse (CYP51A1) gene is overexpressed in Venturia inaequalis strains resistant to myclobutanil. Phytopathology 91:102-110.

Shetty, D. S., Narkar, S. P., Sawant, I. S., and Sawant, S. 2014. Efficacy of quinone outside inhibitors (QoI) and demethylation inhibitors (DMI) fungicides against grape anthracnose. Indian Phytopathol. 67:174-178.

Simmonds, J. 1965. A study of the species of Colletotrichum causing ripe fruit rots in Queensland. Qld. J. Agric. Anim. Sci. 22:437-459.

Sonoda, R., and Ogawa, J. 1982. Growth rate of Monilinia fructicola resistant and sensitive to benomyl on potato-dextrose agar and on peach fruit. Plant Dis. 66: $1155-1156$

Squissato, V., Yucel, Y. H., Richardson, S. E., Alkhotani, A., Wong, D. T., Nijhawan, N., and Chan, C. C. 2015. Colletotrichum truncatum species complex: Treatment considerations and review of the literature for an unusual pathogen causing fungal keratitis and endophthalmitis. Med. Mycol. Case Rep. 9:1-6.

Sun, X., Wang, J., Feng, D., Ma, Z., and Li, H. 2011. PdCYP51B, a new putative sterol $14 \alpha$-demethylase gene of Penicillium digitatum involved in resistance to imazalil and other fungicides inhibiting ergosterol synthesis. Appl. Microbiol. Biotechnol. 91:1107-1119.

Szkolnik, M. 1981. Physical modes of action of sterol-inhibiting fungicides against apple diseases Venturia inaequalis. Plant Dis. 65:981-985.

Talhinhas, P., Sreenivasaprasad, S., Neves-Martins, J., and Oliveira, H. 2002. Genetic and morphological characterization of Colletotrichum acutatum causing anthracnose of lupins. Phytopathology 92:986-996.

Talhinhas, P., Sreenivasaprasad, S., Neves-Martins, J., and Oliveira, H. 2005 Molecular and phenotypic analyses reveal association of diverse Colletotrichum acutatum groups and a low level of $C$. gloeosporioides with olive anthracnose. Appl. Environ. Microbiol. 71:2987-2998.

Tamura, K., Peterson, D., Peterson, N., Stecher, G., Nei, M., and Kumar, S. 2011. MEGA5: Molecular evolutionary genetics analysis using maximum likelihood, evolutionary distance, and maximum parsimony methods. Mol. Biol. Evol. 28: 2731-2739.

Thompson, J. D., Gibson, T. J., Plewniak, F., Jeanmougin, F., and Higgins, D. G 1997. The CLUSTAL_X windows interface: Flexible strategies for multiple sequence alignment aided by quality analysis tools. Nucleic Acids Res. 25: 4876-4882.

Towers, G., Green, K., Weibel, E., Majumdar, P., and Clarke, B. 2003. Evaluation of fungicides for the control of anthracnose basal rot on annual bluegrass, 2002. Fungic. Nematicide Tests 58:T017.

Weir, B., Johnston, P., and Damm, U. 2012. The Colletotrichum gloeosporioides species complex. Stud. Mycol. 73:115-180.

Wells, L. D., Perry, R. S., and McManus, P. S. 2014. Fungicide efficacy and specificity toward fungi in the cranberry fruit rot disease complex. Online publication. Plant Health Prog. doi:10.1094/PHP-RS-13-0024

Wharton, P. S., and Diéguez-Uribeondo, J. 2004. The biology of Colletotrichum acutatum. An. Jardin Bot. Madrid 1979:3-22. 
White, T. J., Bruns, T., Lee, S., and Taylor, J. 1990. Amplification and direct sequencing of fungal ribosomal RNA genes for phylogenetics. Pages 315-322 in: PCR Protocols: A Guide to Methods and Applications. M. A. Innis, D. H. Gefand, J. J. Sninsky, and T. J. White, eds. Academic Press, San Diego.

Wong, F. P., and Midland, S. 2004. Fungicide resistant anthracnose: Bad news for greens management. Golf Course Manage. 72:75-80.

Wong, F. P., and Wilcox, W. F. 2002. Sensitivity to azoxystrobin among isolates of Uncinula necator: Baseline distribution and relationship to myclobutanil sensitivity. Plant Dis. 86:394-404.

Woudenberg, J., Aveskamp, M., De Gruyter, J., Spiers, A., and Crous, P. 2009. Multiple Didymella teleomorphs are linked to the Phoma clematidina morphotype. Persoonia Mol. Phylog. Evol. Fungi 22:56-62.
Wyand, R., and Brown, J. 2005. Sequence variation in the CYP51 gene of Blumeria graminis associated with resistance to sterol demethylase inhibiting fungicides. Fungal Genet. Biol. 42:726-735.

Young, J. R., Tomaso-Peterson, M., De la Cerda, K., and Wong, F. P. 2010. Two mutations in $\beta$-tubulin 2 gene associated with thiophanate-methyl resistance in Colletotrichum cereale isolates from creeping bentgrass in Mississippi and Alabama. Plant Dis. 94:207-212.

Ypema, H., Ypema, M., and Gubler, W. 1997. Sensitivity of Uncinula necator to benomyl, triadimefon, myclobutanil, and fenarimol in California. Plant Dis. 81:293-297.

Zhu, F., Bryson, P. K., and Schnabel, G. 2012. Influence of storage approaches on instability of propiconazole resistance in Monilinia fructicola. Pest Manage. Sci. 68:1003-1009. 